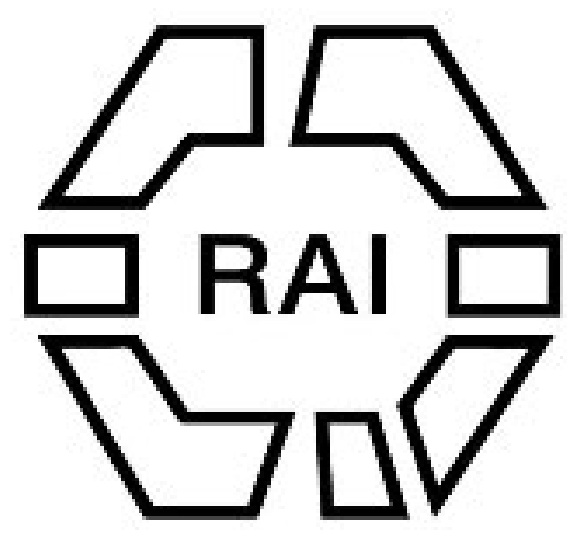

The Hill Tribes of the Central Indian Hills

Author(s): Wm. Crooke

Source: The Journal of the Anthropological Institute of Great Britain and Ireland, Vol. 28, No. 3/4 (1899), pp. 220-248

Published by: Royal Anthropological Institute of Great Britain and Ireland

Stable URL: http://www.jstor.org/stable/2842872

Accessed: 15/06/2014 06:16

Your use of the JSTOR archive indicates your acceptance of the Terms \& Conditions of Use, available at http://www.jstor.org/page/info/about/policies/terms.jsp

JSTOR is a not-for-profit service that helps scholars, researchers, and students discover, use, and build upon a wide range of content in a trusted digital archive. We use information technology and tools to increase productivity and facilitate new forms of scholarship. For more information about JSTOR, please contact support@jstor.org.

Royal Anthropological Institute of Great Britain and Ireland is collaborating with JSTOR to digitize, preserve and extend access to The Journal of the Anthropological Institute of Great Britain and Ireland. 


\title{
THE HILL TRIBES OF THE CENTRAL INDIAN HILLS.
}

\author{
By WM. Crooke, Esq., B.A.
}

I ven'TuRE to aldress you this evening on the subject of a race about which the ordinary Englishman has as yet attained only an imperfect knowledge. Most of us learn what we know of distant races when attention is called to them by war, by some great disaster, by the travels of some bold explorer. But these junglefolk whom we have to consider to-day have hardly ever resisted the British arms; their country has been so little explored by scientific travellers that about a century ago when it first came under our rule it was a terra incomnita, peopled by races of whom wild tales were told, like those which delighted the ancient and medieval world-tales of cannibalism, of men who covered themselves with their ears as they slept, and other common-places of folk-lore. Of Central India the first real account was that prepared by Sir Richard Temple soon after the Mutiny. Since then every corner of these hills and jungles has been explored by a succession of English officers, and a large amount of valuable information has been obtained about these races, much of which lies forgotten in mouldering libraries or in musty blue-books.

But it is only within our own day that more attention from the point of view of ethnology has been directed to these people. This is the result of that wider interest felt in regard to anthropological studies, which is one of the leading characteristics of the science of our generation. It was seen that we had here within easy reach of European observers a congeries of races the investigation of which was likely to furnish much information to the students of the new science. They had lived for countless ages in a state of comparative isolation; it was clear that their origin and distribution suggested a most interesting series of ethnological problems; and while in the recent past Brîhmanism, that most active of missionary faiths, had largely influenced their heliets, it came to be admitted that these so-called indigenous religions had in the early past profoundly aftected Brâlmanism. It was obvious, too, that if their social polity and creeds cleserved enquiry, no time should be wasted. As the newspaper and Board School are playing havoe with our native folk-lore, so the Hindu missionary, the ascetic, like the Jogi and Samnyâsi, were gradually bringing them within the Brâhmanic fold, and it was certain that before long much that was interesting and characteristic roukl be utterly lost. It was also generally admitted that the accounts of the carly observers left much to be desired in wideness and precision. The modern 
student of ethnology requires much more retail in the investigation of custom, ritual and folk-lore than his predecessors.

Hence came the plan of a systematic Ethnographical Survey of Northern India, which was designed to provide a detailed euquiry, based in the main on anthropometry, into the relations of the existing races to each other; and, secondly, a minute exploration of their customs of birth, marriage and death rites, social organisation, religion and folk-lore was proposed. This was carried out first for the great Province of Bengal by Mr. H. H. Risley; it was next undertaken and completed by myself for the North-Western Provinces, and the work is now in progress in the Panjâb and Behâr.

It is mainly the general results of this survey that I venture to lay before you as affecting the jungle tribes and their kindred in the lower settled country. For the people occupying Bengal we have the researches of Colonel E. T. Dalton and Mr. Risley. In the North-Western Provinces I was fortunate enough to hold for five years the post of magistrate of the immense district of Mirzapur, the last refuge in that part of the country of many interesting tribes. Marching through their forests year after year, living amongst them for months at a time quite isolated from other Europeans, continually joining them in the search for big game, a European who ohserves them with interest and sympathy can hardly help gaining some useful knowledge. But unhappily the Indian official has little spare time to devote to pure ethnology. The cares and responsilbility of a district containing a million and a quarter of souls ever press heavily upon him. Hence come the inevitable incompleteness and shortcomings in his ethnological work, which is, as it were, only one chapter in the round of his official life.

Before we can discuss the Central Indian hillman in any detail we must try and form some general idea of his environment. A night or so in the train conveys the new-comer to Indian soil from the sea border which Bombay guards up the slope called in vernacular parlance the Ghatts or steps, the low hills which form the western bastion of the Central Indian plateau. Then begins what is known in varions parts of its length as the Satpura, Kaimûr or Vindhyan range, which may be called the backbone of the Peninsula. To the north of it lie the alluvial valleys of the great Indian rivers-the Panjâb and Sindh, the basin of the Indus and its tributaries, the deserts of Râjputâna, the North-Western Provinces and Oudh, the valleys of the Ganges-Jumna river systems. In wealth, political and strategical importance, in historic interest, this is much the most important portion of the Empire. South of the central range of hills comes the plateau of the Deccan or Southern land, and thence down to Cape Comorin lie what are known as the Presidencies of Bombay and Madras, the dominions of the Nizâm of Haidarâbâd and the kingdom of Mysure.

This range of hills, then, runs almost continuously from west to east for a distance of some eight hundred miles. The highest peaks of the range are little mure than 4,000 feet high, not more than our Ben Nevis; but nowhere are they arranged on any well-defined system. Here the scarp is high and well-marked 
there it slopes gently to the plain below; parts of it are quite unculturable, miles of rock and boulder covered in places with very scanty vegetation; here and there are little fertile valleys, small pockets of verlure amidst the cliffs and jungle. Nowhere is the jungle really heavy in the sense of our popular conception of a tropical forest, like that, for instance, along the course of the Amazon, where the giant trees close in at the summit and exclucle air and light, vast masses of tangled creepers, wastes of malarious greenery. But none of these will you find in the jungle with whose folk I am trying to make you acquainted. Here the jungle consists of low scrubby thickets of trees usually armed with most insinuating thorns; whatever heavy timber ever grew on this arid soil has long ago fallen beneath the woodman's axe or has been destroyed by constant forest fires. In fact, the soil is too poor, the moisture too deficient except for the three months of the annual rains, the sun's heat too fierce to permit the growth of any luxurious vegetation. Hence we naturally find a notable absence of animal lile. The popular conception of a real jungle is a place where you can turn out a tiger, a buffalo or a stag at every acre, or may treal upon a cobra at every step. But here this is not so. A tiger in a country like this needs a range of some forty square miles to supply himself with food, and the deer and the wild pig live only where there is a tolerably permanent supply of water. It is in truth a dreary land, at one time baked like a brick by a relentless sun, at another soaked by almost constant rain, at a third reeking with malaria as the heat draws the surplus moisture from the soil. Agriculture, again, is restricted by the small available area. The thin coating of loam on the hill sides will not admit of constant cultivation; so another plan is invented-a patch of jungle is cut down, the stumps remain in the ground, but the leaves and branches are collected and burnt. The ashes are roughly scattered over the surface, which is broken up by the national tool, the digging stick. This is merely a branch of a tree with the end armed with a spike, a distinctively savage implement from which by a regular series of crolution sprang our modern plough. When the field is supposed to be ready, the seed of the rice or millet is scattered over it, more abunlantly at the top of the slope so that it may be washed clown towards the bottom by the coning rains.

But when the crop is sown the troubles of the husbandman are only beginning. $\mathrm{He}$ is beset on all sides by Nature's beggarmen-the deer, the wild pig, the green parrot, the grasshopper. So he has to gird in his patch with a dense mass of thorns, like what our troops in the Soudan call a zeriba, and he has to sit up at night and fire his old matchlock now and then to scare the beasts. At dawn when he goes home to eat and rest he is replaced by his wife or little boy, who sits all day on a platform and flings stones out of a sling at the parrots. Needless to say, he has no means of watering his crop, and if the rains fail he gets nothing.

The natural consequence is that he would starve one year in every five or six if he possessed no other resources ; and his only feeding ground is the jungle. In 
the first place, it gives him some animal food, but not much. Game is far from plentiful, and most animals are, from his point of view, shamefully wide-awake. His weapons, the bow and his old rusty matchlock, are wretchedly ineffective, and he wounds many a beast which he does not bag. His needs make him the very antithesis of what we call a good sportsman. He will sit over a water-hole and kill, if he can, any beast that comes to drink: stag or hind or fawn are all the same to him. He will lay snares or dig pits round his field with stakes or nooses cunningly arranged, and leave a tempting hole in the thorn palisade through which the poor creature creeps to his death.

But besides this he has sources of food in the myriad fruits, berries, and nuts which the jungle provides. Any of us let loose in such a place with a pointed stick as our only tool would perish straight off of starvation. But the jungleman knows what to dig for, and feeding stuff of some kind or other he can nearly always find. Or if he chance on something poisonous or unwholesome he knows how to scrape and soak it so that its dangerous properties are removed. When a Korwa young lady is married her papa in the fine broad style of the jungledweller points to a hillside and says, "Here is your domain," and such rights are acknowledged, as with us a crossing or a tramp's beat becomes a property.

But let no one delude himself into the belief that there is much charm about such a way of life. To those of us who are satisfied with a little French cookery, an entrée, a bird, a savoury, the jungleman's dinner is sure to be most unsatisfactory. He will eat game which he admits to be a little "high," but which we should call carrion, and his roots and fruits are many of them in the nature of the basest hips and haws which a respectable British blackbird would turn up his beak at.

One thing he does acquire by this course of life is a marvellous insight into Nature and her secrets. His eyesight or power of hearing is not, I think, by nature nuch better than ours, but he will hear or see a tiger creeping down a ravine long before the English sportsman will. Every sound in the forest has a meaning for him-the grunt of the baboon as the tiger comes beneath his tree, the hoarse alarm bark of the stag. From the way the vultures hover in the air he will tell whether the tiger has finished his meal or is still tearing the carcase. Every foot-mark, a displaced pebble, a broken grass stalk will tell him something, what beast has passed there and how long ago. We of late hours and crowded rooms and artificial light look on such powers alnost as a miracle; but it is really only the result of the fact that he has thoroughly adapted himself to his environment, and this he must do or starve.

The problems of North Indian ethnology, then, centre round the interrelation of the two stocks popularly known as the Âryan and Dravidian. The ordinary theory which has come to be included even in our school-books tells us that a race known as the Âryas, or nobles, lived somewhere to the north of the peninsula, in what are called the Pamîrs, or somewhere beyond the Hindu Kush, or even in the forests of Lithuania. From this central point, wherever it may have been, there 
is said to have occurred in early times a great dispersion. This gave rise to the existing European races as well as those of Persia and India, of whom we ourselves are kinsmen, a sort of distant cousins.

The objections to this theory are that it is in the main based on philology, which though an important ethnological factor, is not a final test of race; and, secondly, that, particularly in Europe, investigations of the barrows, the burial places of the prehistoric races, have shown that a large part of the population still resembles in type the earlier races who lived in those countries, associated with extinct animals like the elephant and cave-bear long hefore the earliest date which can be assigned to the inroad of the Aryans.

To return to the Dravidians of India, a name derived from the Sanskrit Dravida, usually applied to the country known as the Coromandel Coast, stretching from Madras to Cape Comorin, and itself probably of non-Aryan origin, the most probable theory suggests Northern Africa as the earliest seat of prehistoric man, and many indications tend to show that his evolution from the anthropoid apes may have occurred there in the Pliocene age. From this centre of dispersion it is probable that Europe was peopled by the earliest races who were either pre-glacial or inter-glacial, that is to say, occupied the country before the Ice Age or in a break between two advances of the ice crust. Another section of the same race probably passed eastward along the Indo-African continent which was then continuous, the intervening space, which is now the Indian Ocean, being dry land of which fragments are represented by a group of islands or shoals, such as Madlagascar, the Amirante, and Seychelles Islands. Survivals of these colonists of the Negrito type possibly occur in the Veddas, a degraded jungle tribe in C'eylon, and in the hairy-faced Todas who are familiar to ethnologists as occupying the Níligiri plateau in Southern India and practise a remarkable form of fraternal polyandry.

As regards the existing races of Central India, the absence of distinctly woolly hair, which, though it may appear in occasional isolated types, has never been distinctly traced as a general racial characteristic, coupled with their lack of prognathism and brachycephaly, is a difficulty in assuming the prevalence of a distinctly Negrito type in the present population. Before this question can be definitely settled we need much further anthropometric evidence from Eastern Africa to admit of detailed comparison with the Indian races. It is possible that further investigations may modify the current theory as to the Indo-Negrito element. Thus, the Nâgas of the Assam-Burmese frontier usually classed as Mongoloid, have a cast of features which present some analogy to the Negro tribe as will appear from the pictures which I now proceed to show you.

3. Here we have a picture of an Angâmi Nâga, a chieftain who commanded against us in the fighting at Kohima and Khonoma.

5. A Lhota Nâga boy.

6. Lhota Nâgas.

7. Mao Nâgas. 

8. Rengma Nâgas.
9. Tablung Nâga woman.
10. Jaypur Nâgas.
18. The Namsingia head-dress.
19. Angâmi Nâgas in festival costume.
21. Angâmi Nâga, interpreter.
24. Kûki women.

But as regards the Dravidian element in the races of Central India, it is now generally admitted that their origin must be sought for elsewhere. "In the Dravidian type," to use Mr. Risley's summary of the anthropometric evidence, "the form of the head usually inclines to be dolichocephalic, but all their other characteristics present a marked contrast to the Âryan. The nose is thick and broad, and the formula expressing its proportionate dimensions is higher than in any known race, except the Negro. The facial angle is comparatively low; the lips are thick, the face wide and fleshy, the features coarse and irregular. The average stature ranges in a long series of tribes from 156.2 to $162 \cdot 1$ centimetres ( 5 feet $1 \frac{1}{2}$ inches to 5 feet $3 \frac{3}{4}$ inches); the figure is squat and the limbs sturdy. The colour of the skin varies from very dark brown to a shade closely approaching black." The most distinctive type of Dravidians is found among the Mâlê Pahariyas of the Râjmahal Hills and the Mundas and Orâons of the Chota Nâgpur platean.

But it would be a mistake to suppose that we have here a single race with uniform physical characteristics. Perhaps it may be easier to make this fact apparent from photographs of some representative groups from the North-Western Provinces which I shall now exhibit. ${ }^{2}$

14, 15. Here you have a group and a single man of the Korwa tribe, perhaps the most primitive race surviving in these provinces. They live in small isolated communities, supporting themselves mostly on jungle fruits and roots, a curiously shy people who liave come little into contact with Europeans. In one of their villages which I visited only one old man had ever before seen an Englishman, and that when he was a boy. They are men of a fine vigorous type, but those represented in these pictures range between only 5 feet and 5 feet 5 inches in height.

16. The next group, called Biyârs, are rather more Hinduised than the Korwas; here the higher of the two is only 5 feet $3 \frac{1}{2}$ inches ligh.

17. Next come a pair of Parahiyas or Hillmen, who have, as you will observe, more marked Dravidian characteristics.

18. These are followed by a Gond, hardly a good representative of the more primitive branch of the tribe who live further south in the Central Provinces.

19. Next comes a Panka, a village weaver and serf in the hills.

I, Intro., xxxii.

2 These pictures are reproduced in Crooke, Tribes and Castes of the North-Western Provinces. 
20. Following him is a family of Patâris who are the family priests of the Majhwârs, a tribe closely allied to the Gonds.

21. Next comes a Ghasiya, a very good example of an almost pure Dravidian.

22. Next comes a Bhuiyâr, who, as you will observe from the breadth of his nose, is a tolerably pure Dravidian.

23. Following him is a party of Mânjhis or Majhwârs, who are almost pure Gonds. They carry, you will observe, the Mândar or sacred drum of the tribe, the body made of enrthenware, and the ends covered with goatskin. It occupies an important part in the religious rites of the tribe.

24. These are followed by a party of Cheros, also fairly pure Dravidians; but here it is necessary to distinguish, because one branch of the tribe has become largely Brâhmanised, while others retain much of their primitive character.

25. Next I show a family of Kols, known in Bengal as Hos or Mundas, from whom a branch of the Dravidian race has been called Kolarian. But recent enquiries have shown that the distinction between the Kolarians and the other Dravidians is merely linguistic and not based on any really physical lifferentiation.

26, 27. In the next two pictures we have the Agariya, the primitive ironsmelter of the hills. Interesting questions arise as to the origin of this industry, on which I may say something later on. Here you will notice the double goatskin bellows, which he works with his feet, and the hammer of a form closely approximating to the neolithic type, with which he beats out the charcoal and other impurities from the ingot.

29. Lastly, comes a representative of the Hill Doms, who take many forms, from that of an artizan in the lower Himalaya to a singer, and finally, the most degraded outcast in the Plain country, a worker in bamboo, a houseless wanderer, a thief, a scavenger, whom even to look at is, for a pious Brâhman, a pollution.

I pass on to consider the connexion between these Hill Dravidians and the great servile or agricultural population of the Plains, by which I mean generally the valleys of the Ganges and Jumna, that vast mass of simple, peaceful, orderly people, whose chief fault in our eyes is that they propagate their species withont any regard to their resources, and are thus a constant burden upon the country, while in seasons of drought, as in recent famine, they become a source of enormous expense and anxiety to the Administration. What we have now to attempt is to examine how these people are related to the Dravidians of the Hills, and perhaps I cannot introduce this part of the subject of my paper better than by showing you a few typical representatives of them, so that you mity be able to form some comparison between the two groups.

1. Here, then, we have, first, a couple of Chamârs, the old man holding up in his hands a pair of ordinary country shoes. The Chamâr is primarily a tanner or currier, as his name implies, and from his association with hides, and particularly that of the sacred ox, he is detested by orthodox Hindus. But besides working 
in leather, he also farms, does field work and general village drudgery. English officials are often accused of talking in lakhs. But some idea of the difficulty of dealing with these lower races may be expressed by the fact that of these Chamârs alone we have in the North-Western Provinces nearly six millions, about half as much again as the population of Scotland.

2. Next come representatives of an interesting set of people, the Banjâras, who are wandering carriers of grain, with a curiously distinctive dress, perhaps the most interesting race in the Plains, now being seriously affected from the competition of the railways with their hereditary inclustry.

3. Following these we have the Banya, the corn-chandler, pawnbroker, money-lender, the Shylock of India, hardly a popular personage to those who get into his books, but a sound capitalist, withont whom the Empire would be hard set to pay its way.

4. In the next picture we meet another class, the Fakir or so-called ascetic, the idle, loafing vagabond who wanders about the country begging alms. In the North-Western Provinces there are no less than two millions of these sturdy beggars, nearly half that of the county of London, one in every twenty of the whole population of the Province.

5. With him I give a Vaishnava Fakir, one of that class of ascetics who derive most of their inspiration from the teaching of Buddha, and in particular a very careful regard for all kinds of animal life.

6. Next, as illustrating the so-called Âryan branch of the people we have a group of Brâhmans, the Levites of the Hindu community, primarily priests, but also working as clerks, soldiers, husbandmen, and other occupations regarded as pure.

7. The next picture is intended to show the common dress of the women of the Plains.

8, 9. This is followed by two husbandmen ploughing, one a Jât, one of our finest North Indian races; the other a hillman.

10. In the next picture we have a group of Mahâbrâhmans, the funeral priests of the Hindus, not real Brâhmans of the learned priestly class, but a lower class of officiants drawn from some of the lower races. It is needless to say that their duties cause them to be abhorrerl and despised.

11. Represents one of the Dravidians of the Plains, a Bind, who is a menial labourer and cultivator.

12. Shows a variety of the Dom race of whom we have already seen an example from the hills. This is one of the sub-caste of Dharkâr, who are partially civilised and live by working in rope and bamboo.

28. Another set of Doms.

13. Lastly, to show quite another type comes a group of Bhotiyas from Tibet, pure Mongolians, perhaps the only Buddhists whom we are likely to meet in the Plains.

We are now in a position to discuss the racial affinities of these Dravidians within and without the Indian Peninsula. 
We have seen that the Southern Indian tribes, such as the Todas, possibly represent a fusion of Melanochroid Caucasic and Austral-negro blood at a remote period in a now submerged Indo-Austral region. But, as has been shown, the absence of prognathism and woolly hair forbids us to find in the Dravirlians of to-clay anything like a strong Negrito element. It has heen the habit to regard them as Mongoloid, but Mr. Risley's investigations render this improbable. It seems preferable to regard them as belonging to a second and independent migration from the direction of the original African headquarters, which possibly passed into Asia by a more northerly route than that of the primitive Negrito element, traceable in the Veddahs and Todas. This type varies on the one hand with assimilation to the earlier Negritos: but more particularly by fusion with what we popularly call the Âryan stock.

It must, however, be remembered that the aggregate of tribes popularly known as Âryan has been so grouped mainly on linguistic, not racial character. It has been assumed that there was an original Ur-Âryan tongue from which the Âryan languages were derived by regular descent. But the original home of these Âryans has never been satisfactorily ascertained. Opinion seems now to be inclined to regard these Âryans as not one simple "ethnical stock, but an amalgam of many Caucasic and no doubt some Mongoloid elements, leavened by an original Xanthochroid strain, and endowed with a certain racial uniformity by the immense preponderance of the Caucasic physical character and by the general adoption of Âryan speech, traditions and institutions."'

On the fact, then, of the allied origin of the Âryan and Dravidian races, or in the continuous amalgamation of these two strains of blood seems to depend the remarkable fact that, as shown by an examination of the cephalic indices, there is a striking uniformity in the existing races occupying Northern India. The consideration of this question depends on the survey of a vast mass of statistical evidence with which I must not trouble you at present. The results have been summarised by Mr. O'Donnell for Bengal, and by Surgeon Captain DrakeBrockmann for the North-Western Provinces. ${ }^{2}$ Thus, generally speaking for the latter, taking four main castes-the Brâhman representing the Âryan, the Kâyasth Medium Âryan, the Chamâr Hinduised Dravidian, the Kol fairly pure Dravidian, the cephalic indices are respectively $73 \cdot 7,73 \cdot 3,73 \cdot 9,73 \cdot 8$. For Bengal Mr. O'Donnell writes:-." It thus appears that the Brâhman is at one end of the scale and the cultivated Kâyasth at the other, whilst at the top of the Behâr list the fisherman, priest, farm-labourer, landlord and cow-herd are in close proximity. In the North-Western Provinces the Kshatriya or Râjput soldier, and the Khatri or Râjput trader stand at opposite extremes-rat-catchers, carpenters, dancing women, cultivators, toddy-drawers, and priests coming in between. No evidence could be more convincing, if anthropometry has any meaning. The Indian races and tribes in the valley of the Ganges from the Afghân frontier to the Bay of Bengal are so

1 Keane, Ethnology, 410.

2 Crooke, Tribes and Castes of the North-Western Provinces and Oudh, i, Intro., xxx scqq. 
absolutely intermingled in blood, that it is impossible to discriminate between the skull characteristics of the castes or functional guilds which have grown up under later Brâhmmanical usage."1

Here the case is perhaps put too strongly; but it to some degree justifies the distrust felt by one school of anthropologists in the value of skull measurements as a final test of race. ${ }^{2}$ Hence another factor, the breadth of the nose, has been selected as a criterion. Even the most casual observer cannot fail to remark the basal breadth and coarseness of the Dravidian nose as compared with this more finely moulded feature in the higher races. Mr. Risley has gone so far as to say that "it is scarcely a paradox to lay down as a law of the caste organisation in Eistern India that a nan's social status varies in the inverse ratio to the breadth of his nose."'s Here again, as Mr. O'Donnell and Surgeon-Captain DrakeBrockmann point out, there are startling variances in the figures, which illustrate the necessity of caution. ${ }^{*}$

In the present state of our knowledge, then, on this subject the most reasonable view seems to be that while on the whole there is a remarkable uniformity of type judging from the skull measurements of the races of Northern India, and the pure Âryan type is not so readily separated from the Dravidian as it has hitherto been the habit to suppose, there may be minor or subsidiary variations in the cranial form which may lead to clearer knowledge. The total population of these three great Provinces, Bengal, the North-Western Provinces and the Panjâb is about one hundred and forty millions (Russia in all contains about one hundred and thirty millions). The number of measurements hitherto made is quite inadequate to form a sure basis for deciding the ethnical affinities of such enormous masses of men. Besides this much investigation on the East African side will be required before the materials for decision are available. The obvious moral is that measures are urgently needed for the prosecution of anthropometry in this part of the world on a nuch wider scale than has hitherto been attempted.

The inference suggested by this summary of results is then, that the so-called Âryan invasion of the Peninsula probably assumed a form quite different from the usual conception of it. It was apparently never an invasion in the common sense of the word, an imroad of a fully organised nation, overwhelming and enslaving the indigenous races, such as was, for instance, that of the Turkish tribes into Europe. The colonisation of Central Asia by the Mongol races probably took place through the Indian Peninsula, and this was followed by a continuous southward movement of the Âryans which was only part of that great series of emigrations which went on continuously during prehistoric times. Their incoming may have been gradual and spread over vast eras of time: it may have taken the shape of successive waves of colonists, never very numerous, and establishing their superiority more by the influence of their higher culture than by actual brute force. In some places

1 C'rooke, Intro., cxxxvii.

2 Keane, ibid., 177.

- Risley, ibid., i, Intro., xxxiv.

+ Crooke, ibid., i, Intro., xxviii seq. ; cxxiii. 
they may have become real over-lords of the races which they found in the country: in other parts the conquered may have absorked their conquerors. This theory would in a measure account for some of the most difficult problems in the ethnology of upper India-the increase of dolichocephaly towards the north-west frontier, the prevalence of a higher type in Kâjputâna on the fringe of the western deserts, the occurrence of the Jâts and Gûjars in the valleys of the Indus and Jumma, who possibly represent an independent boly of colonists. It would also explain the gradual spread of the Âryan culture towards the East as marked by successive stages of occupation from Âryavartta, the sacred land of the Âryans in the Eastern Panjâb to Indraprastha or old Delhi on the Jumna, thence to Hastinapura on the Ganges, to Ayodliya on the Sarju, and later on along the Gangetic Delta.

This line of argument, again, suggests what seems to be a prevalent misconception of the character of the conquest of the pre-existing races by the Âryans. The common view is that the pure Dravidians, as we now find them alung the hilly backbone of the Peninsula, were pushed back into these inaccessible retreats, as the Celts were driven into Wales by our Teutonic forefathers, the existing races of the Plains being that portion of the earlier people which was conquered and enslaved. This theory, however, seems to be inconsistent with what we know of the method in which conquering races occupy a tropical or semi-tropical country. Such occupation does not follow the line of the fertile plains and rich alluvial valleys, simply because the lowlands are generally covered with impenetrable forest, swarming with dangerous beasts and more dangerous malaria. It rather follows the course of the lower hills which flank the riverine valleys. Hence it seems not improbable that the original seat of the Dravidians may have been in the mountainous region where we meet them at present. The earliest Âryan legends strongly suggest the conclusion that the lowlands were even in their time an inaccessible jungle, such as travellers of to-day find in the valleys of the Amazon and its tributaries. The forests along the skirts of the alluvial tract were probably then as they are now, comparatively open. If the arrival of early man in India was, as may have been the case, antecedent to the geological convulsions which raised the Siwâlik range, the Ganges valley may then have been a tidal estuary, becoming in the course of time gradually silted up by the detritus of the great Himalayan rivers, and as it grew became clothed with thick malarious jungle.

It seems not improbable, then, that it was in the southern plateau that the first Dravidian settlements were formed. Then as now they may have supported life mainly from the products of the fairly open jungles which formed their early home, and there they evolved those rude industries which form their mode of livelihood even to the present day.

This suggestion seems to be confirmed by the fact that it is not in the rich alluvial plain, but on the southern plateau that we find the remains of the most primitive life, the dolmens beneath which they buried their dead, the inenhirs which marked the graves or formed a home for the ghosts of their famous chiefs or 
priests, the rude stone implements with which they waged war on the wild beasts. There is, I believe, no instance of the occurrence of such remains in situ in the river valleys of the north. They abound in the suthern hills and in some places as at Kon in Mirzapur, I have myself seen one of the prinitive factories where these weapons were chipped and ground.

Further, there seems little doubt that these people were up to comparatively recent times in the Age of Stone. This is shown by the forms of the implements which they use to the present time, which distinctly reproduce in metal the neolithic forms. Less certain is the evidence from rock paintings in the Vindhyan caves discovered by Mr. J. Cockburn, which are said to represent the slaying of the Sâmbhar stag and the rhinoceros by jungle-folk armed with stone weapons: These need not necessarily be very ancient, as the Sâmbhar still abounds in these hills and Akbar, a contemporary of (queen Elizabeth used to hunt the rhinoceros near Chunâr. As Dr. Ball has shown, the Khariyas appear to have been in the Stone Age quite recently. ${ }^{1}$

The same result is arrived at from certain survivals in custom, in which iron is regarded as a substance invested with mystic powers, and the iron-founder supposed to be a sacred or uncamny personage-a feeling which I need not remind you is a wide-spread feeling among savages. Thus, the Magahiya Doms-a very primitive race-boycott any nember of the tribe who uses an iron implenent in committing a burglary. These people in taking an oath clear a piece of ground and plaster it as if for sacrifice; they then swear on a piece of iron and a copper coin placed in the centre. ${ }^{2}$ So the Pankas, pure Dravidians, swear on a piece of iron placed in a drinking vessel; and the Nats make their oath on a bit of copper. ${ }^{3}$ The same feeling shows itself in the very common use of iron, copper or brass as scarers of demons. The young mother, the bridegroom, the mourner under taboo all protect themselves with one or other of these metals. ${ }^{4}$

I have referred to the iron manufacture carried on by the Agariyas. It would be an interesting problem, with which I have now no time to deal, to inquire whether this was an inclependent discovery made hy the Dravidians or taught them by the Hinclus. Iron, though known to the early Iranians, does not appear in the literary monuments of the Hindus till the close of the Vedic period, and then, as in the Homeric poems, seems to have been scarce and valuable. The wonderful iron pillar at Delhi, perhaps the oldest iron monument in the country, is 60 feet long and weighs 17 tons. How such a mass of wrought-iron could have been forged is a standing wonder to metallurgists of our time. It bears an inscription dated in the third century of our era. How much older it may be no one dares to say. Needless to say we have no literary evidence within the Dravidian area, and, as far as I am aware, no definite tradition regarding its origin. It is

- Crooke, Popular Religion and Folk-lore of Northern India, ii, 11, 1.j. 
possible that indications of the origin of the art in Central lndia may be found in the shape of the furnace or bellows and in the mode of manufacture.

I would suggest, then, that the present Dravidian jungle-races may have occupied their present settlements from the very earliest times, and that so far from having been pushed back into the rugged hill tract by the advancing Âryans, the course of their migrations may have been very different. Possibly the impulse to clear the fertile alluvial valleys may have come from the Âryans, a race of farmers and breeders of cattle. In this task they were probably aided by bodies of Dravidians migrating from their forest homes and gradually losing their identity in the presence of a people of superior energy and intellectual power. To this day the Dravidian, like the Thâru of the marsh lands at the foot of the northern hills, is the great pioneer of civilisation. It is he who is gradually converting these immense fens and savamnahs of grass and reeds into fertile rice fields. This may have been the task of the Dravidian race for countless generations; even now as in the past his work, one of enormous importance to the world, has met with no recognition. This task he is able to perform, because, though not nialaria-proof, he endures it better than the other races.

But there is another impuise working in the same direction which it needs an imaginative savage thoroughly to understand. Among primitive people accustomed to the belief that disease is due to evil spirits, it has ever been a desire to seek communion with the divinities of earth and hill and jungle, who are in their belief the active agents in bringing sickness and death. Obviously the denizen of the jungle is more likely to be in communion with these local powers than the foreigner, and without his aid forest reclamation could hardly progress. Hence it comes that even to the present day the priests of the local gods, both in hill and plain are recruited from the most secluded and least progressive of the jungle-folk. I I nay go even farther than this, and suggest that as the Majhwâr Gonds have selected out of their own body a class of local priests, the Patâris, the example may have led to the evolution of the Brâhman priest on Indian soil, when the advancing intricacy of religious ritual demanded the services of a functionary more skilled in the art of spells and incantations than the original Âryan housefather priest. From this point of view it is significant that some branches of Hindu ascetics, such as the Jogi and Sannyâsi, retain many practices which, whatever be their origin, are obviously not Hindu. Thus, they do not wear the scalp-lock; they either never cut their hair or shave it off completely; they never burn their dead, but bury them or fling them into rivers, and when they bury they place the corpse in a sitting posture with the arms supported by a crutch-all customs quite opposed to Hindu ritual. ${ }^{2}$

The same feeling in regard to the jungle-folk comes out in certain rites and privileges which they enjoy to this day. Thus, the Khangârs act as marriage

1 Risley, Tribes and Castes, i, 475 ; ii, 83, 309 ; Crooke, Tribes and Castes, i, 8 ; ii, 85, 333 ; iii, 322 ; Popular Reliyion, ii, $9 \tilde{J}$.

2 Crooke, Tribes and Custes, iv, 27\%. 
priests for the Bhadauriya Râjputs; one of the Mîna tribe always invests the Mahârâja of Jaypur, a Hindu of the Hindus; the Sânsyas, a nomadic thieving race, act as bards and genealogists to the Hindu Jâts. ${ }^{1}$ To this day the special function of watching the fields at night in Hindu villages is assigned to Dravidians, apparently because as owners of the land they are more in touch with the jungle and its beasts, with the evil spirits which walk in the darkness.

This brings me to another branch of my subject which is perhaps of wider interest than the ethnological questions which we have thus hastily surveyed. What we have now to note is some survivals of primitive custom. Their religion, a compound of animism, fetishism, and a crude demonology, is beyond the scope of this paper.

This is the place for the explanation of a fact which has given rise to some criticism. It is generally admitted that for many of these tribes there is ample evidence that at one time they passed through what is called the totemistic stage. We find numerous sections the titles of which are obviously drawn from sacred animals, plants and other objects; we have many instances in which the section ascribes its origin to the so-called totem ; there are many cases in which the totem is treated with respect, and any attempt to destroy or injure or eat the totem is prevented by a rigid taboo. On the other hand, many instances might be quoted where a section which on these indications might be treated as totemistic does not specifically taboo the assumed totem, or rather, if we may put the case so, transfers the taboo to something else which is not the tribal totem. This, on the face of it, suggests doubt as to whether these tribes did ever pass through the totem stage, or whether the original idea may not have been so worn away or overlaid by other and antagonistic beliefs that nothing now remains but the bare husk of the primitive belief, and this may in later times have originated from another line of thought. Thus, to give a single instance, when we find the totem belief in this stage of degeneration, it is open to any one to say that the connection of the sept or section with the sacred beast or plant is merely a case of tree or animal worship, and need not necessarily imply that the worshippers of it were ever consciously in the totem stage. This view of the case is, no doubt, in some instances correct, and it is quite possible that some usages and beliefs have been from time to time labelled as totemistic which may be explained in another way. When we have to deal with the mere husk of a custom or rite caution is clearly necessary, and some of us who have been carried away by the suggestiveness of the totem theory, which threw novel light on many obscure facts, and enabled us to bring at least into a semblance of order many conceptions which were merely isolated fragments of belief destitute of any reasonable meaning, may have gone too far. This is not to say that in the present stage of the controversy the totem theory must be altogether abandoned; rather that it may be necessary in some cases to revise our co-ordination of the evidence, or perhaps to admit that there is no common master-key to all the mysteries, and that while the human

1 Crooke, Tribes and Castes, iii, 229, 490 ; iv, 279.

New Series, Vol. I, Nos. 3 and 4. 
mind works with curious regularity through the whole range of savage thought, the local factor, or what the mathematicians call the personal equation, must be more closely weighed. But to return to these Dravidian clan taboos and the curious variances which they present-one point must be kept carefully in mind. Nowadlays most of the leaders of the totem school are prepared to admit the weakness of the evidence for totemism within the so-called Âryan area. Here possibly tree and serpent or animal worship will be found to explain most of the facts witliout the necessity of calling in the aid of totemism. This fact profoundly affects the question of the Dravidian taboos. Here, I imagine, we can watch the conflict of two sets of beliefs, which has modified the primitive tradition. The Hindus, for instance, protect the cow by a powerful religious sanction, while the Dravidians used to sacrifice and eat her. So the Dravidians used to live on many jungle-beasts which the Hindu considers impure-the rat, the squirrel, the lizard, the crocodile. At present it is only the casteless, vagrant tribes in the Plains which have been able to resist the pressure of the superior race to class such creatures as abominable. Here and there the custom is in process of change, the more Hinduised members of the tribe, with a view to social advancement, adopting rules which prescribe extreme purity; the more conservative or less advanced section adhering to the primitive yractice, but in some cases with real or assumed secrecy.

Thus, under Hindu influence there has been a tendency to replace the old totem or sacred beast by some eponymous ancestor drawn from the ranks of Hinclu saints or worthies, and here often the familiar influence of folk etymology comes into play. Thus Rikhmun, the divine ancestor of the Bhuiyas and Musahars, who is called a deified Rishi or saint, is probably in reality Riksha, the bear: so Kachchapa, the tortoise, has become the saint Kasyapa, and Bhâradvaja, the lark, turns into a third Hindu worthy.

With so much reservation about totemism, we may say that among these people it appears specially in connection with marriage, the primary social unit being what may provisionally be called the totem clan, which is exogamous; marriage and sexual intercourse between members of the clan being severely forbidden. Later on, as under Hindu influence the totem link became weakened, it became necessary to invent special titles or watchwords to define the exogamous groups, as we find in the case of the Santâls and Halwâis, among the latter the passwords being embodied in a series of mnemonic metrical formulæ. ${ }^{1}$ These exogamous sections or septs later on became combined into the existing tribes, and this combination appears to date from the period of the adoption of descent through the father in lieu of the matriarchate, which, as we shall presently see, was probably the primitive rule. The method in which this amalgamation takes place may be illustrated by the analogous process among the West African tribes. Thus one of the Dog clan marries a Leopard; under the old system the children would be Leopards ; but when the father's share came to be recognised they would

1 Risley, ibid., ii, 227 ; Crooke, ibid., ii, 482 seq. 
be Dog-Leopards, and would so belong to two clans. These children in the same way marry into two clans, the Cat and the Snake, and their offspring would belong to four clans. ${ }^{1}$ This system would obviously soon become unworkable and the clan rule has to be replaced by some other formula, as, for instance, by prohibiting the marriage of any descendants of a common pair or tabooing the intercourse of cousins, which is actually what has happened among the more advanced Dravidians, while the Gonds marry cousins by preference.

There are also various indications which go to show that in India this tribal syncretism may be of comparatively modern date. This is shown by the adoption of a purely occupational title for the tribe which is the result of such an amalgamation of septs or sections. This is the Hindu method. Among the Dravidians the aggregate so formerl is commonly designated even by a vaguer term, such as Bhuiya or "landowner," Ho or Kol, "men," Mûnjhi, Majhwâr, "middlemen"; Pahariya, Dhângar, "hillmen"; and so on. And the same conclusion follows from the fact that the boundaries of many of these tribes are even now ill-defined. The Mundas, for instance, are recognised by the Khariyas as elder brethren; Mundas sometimes marry Khariya women, but will not give brides in exchange. So Kharwârs and c'heros are traditionally commected: the Cheros used not long ago to intermarry with the Bhuiyas, but the latter have refused comnubium since the Cheros have tiken to intermarrying with Kols. ${ }^{2}$ Many of the lower tribes, again, habitually recruit their numbers from outsiclers: others, like the Pâsis, admit the children of their women and care little whether the father was a tribesman or not. ${ }^{3}$

These combinations, again, display no real permanence. New groups are ever being formed and recombined on the basis of some change of custom, such as the abolition of the rule of infint or widow marriage, some taboo regarding food or the like. Thus, among the Bhuiyas of Lohârdaga and Mirzapur the olı tribal system of exogamy seems to be falling into disuse, and many groups which were once exogamous are now endogamous. ${ }^{4}$ So the Kurmis are giving up their old totemistic sections in favour of artificial groups. ${ }^{5}$ All these races, too, have become conscious that the totem rule of exogamy does not prevent close intermarriage, so they have been obliged to reinforce it by the establishment of personal prohibited degrees which prevent the marriage of cousins or those directly descencled from one common ancestor. New local sections are thus constantly formed, but with an inconsistency, in some respects natural, they still in some cases maintain the old grouping, or prefer to bury their deal in the ancient tribal cemeteries."

It may also be suspected the the size of the group has considerable influence in deciding the question of exugamy or endogamy. This is clearly shown in the

1 Ellis, Yorubu-speaking Peoples, 175.

2 Risley, loc. cit., 1, 466, ti3; Crooke, ibid., ii, 106, 217.

3 Crooke, ibid., iii, $1+3$.

4 Risley, ibid., i, 114; Crooke, ibid., ii, 73.

Crooke, ibıd., iii, 351.

- Crooke, ibrd., ii, 74, 174; iii, 169, 289, 337 ; iv 112. Risley, ibid., i, 469 ; ii, 147 
case of the vagrant tribes, who possess a form of horde exogamy in which marriage is prohibited within the gang, as in the case of the Sânsyas or Hâbûras. ${ }^{1}$

I have said that in all probability these tribes have passed through the stage of the matriarchate, or where descent is counted through females. It may be worth while considering what evidence exists on this point.

We have, in the first place, a long series of legends which attribute the descent of the tribe to a female ancestress, such as the Agarwâlas from Mâdhavi, the Musahars from Savari, the Kanjars from Nathaiya ${ }^{2}$; and this story in many cases takes the form of naming as the ancestress of the present clan a pregnant woman who was saved from the massacre which destroyed her brethren. This tale is told, for instance, of the Chamar Gaur Râjputs, the Ghatwâl Jâts, the Khangârs, the Thatheras. ${ }^{3}$ Or, by another version, they spring from an innocent wife who has been discarded on some false charge, as the Mochis, the Kânhpuriyas, the Rors, who sprang from Sîta when expelled by Râma Chandra, and Lakhana Deva, the formder of the Sombansis, was a posthumous son born in exile. ${ }^{4}$ This, I need hardly remind you, is a very favourite motif of many folk-tales, as, for instance, in the Hindu tale of the Son of Seven Mothers. ${ }^{5}$

We have, in the second place, many cases in which the sister's son acts as the funeral priest. This is the case with Doms, Hâris, Tatwas, Basors, Beriyas, Bhangis and other menial races. ${ }^{6}$ In other cases this duty is assigned to the son of a female cousin or son-in-law. Among the Dhânuks, when a man is poor he feeds at the death rites only his sistor's or daughter's husband; among the Bhuiyârs the sister's son is held in particular honour, and periodical gifts are made to him, as to a Brâhman. ${ }^{7}$

Thirdly, we find relations on the side of the bride acting in many cases as officiants at marriage. Thus, among the Bâwariyas, it is the husband of the bride's sister who acts as priest; among the Kanjars it is the sister of the bride, her husband or daughter, who performs the circumambulation rite; anong the Bhuiyârs it is the bride's younger brother who pours rice over the pair. ${ }^{8}$ Often, as among the Majhwâr's, it is the sister's husband of the bridegroom who acts as best man, arranges the marriage or carries the bridegroom in his arms into the marriage booth. ${ }^{9}$

Even more important is the prominent part taken by the mother of the bridegroom in the marriage rites of the Musahars, while among the Majhwârs and

( Crooke, ibid., iv, 279 ; ii, 4 it.

" Risley, ibid., i, 5 ; Crooke, ibid., iv, 17.

${ }^{3}$ Crooke, ibid., i, 78, 195 ; iii, 33, 228 ; iv, 407.

' Risley, ibid., ii, 95 ; Crooke, ibid., ii, 118 ; iv, 244, 327.

- Temple, Wide A wake Stories, 101.

${ }^{6}$ Risley, ibid., i, 245, 316 ; ii, 300. Crooke, ibid., ii, 325, 335 ; i, 226, 246, 288 ; ii, 183, 285 ; i, 83.

- Risley, ibid., i, 245. Crooke, ibid., i, 246, 288 ; ii, 273, 95.

" Crooke, ibid., i, 234 ; iii, 1+2 ; ii, 92, 62.

' Crooke, ibid., iii, 422 ; iv, 65 ; ii, 291 ; iii, 244 ; ii, 87 seq. 
Mârwâris she solemnly offers her breast to him as he is starting to fetch home his bride. $^{1}$

Lastly, comes the important part played in the marriage rites by the maternal uncle or mother's brother. Thus he very often arranges the marriage of his nephew; or he is trustee of the bride's peculium; or he digs the sacred earth for the wedding; he takes round the wedding invitations; he lifts the bridegroom into the house of the bride; or the maternal uncle on each side give the wedding clothes or other gifts to their nephew or niece. ${ }^{2}$ Finally, he is sometimes, as among the Mahesris, the marriage priest, and takes the bricle in his arms seven times round the bridegroom; or, as among the Doms and Jharkîrs, he pours water on the hands of the pair and blesses them. ${ }^{3}$

This leads to the consideration of the forms of marriage in force among these races. At the outset it may be said that any mode of connexion between the sexes which does not contravene the rules of exogamy, and is approved by the kinsfolk, ranks as a marriage with all its usual incidents and privileges. It is a later development of custom which draws any distinction between the children of a bride married as a virgin, a widow or other woman whose connexion with a man is legal under their marriage code.

In dealing, however, with their marriage-law the same difficulty meets us as in the case of their social structure. Everywhere we find merely husks of early custom which have been overlaid by conceptions borrowed from other races. Hence the original theory on which they were based is often obscure, and they may be interpreted in various ways according to the line of influence which was for the time prepotent.

Thus, to take the very primitive rite of group marriage, of this, in the first place, we seem to find a survival in the rule that all marriages more or less and in particular the less regular forms, such as widow marriage or the Levirate, that is to say, the appropriation of the wife of a dead man by his younger brother, must be carried out with the sanction of the Panchâyat or Council consisting of the adult and married males of the tribe. This seems to take us back to a time when the woman who became derelict in consequence of widowhood or desertion came ayain under the general control of the clansmen.

Secondly, we find indications pointing in the same direction in the rule so prevalent among these races that prenuptial incontinence, provided the lover be a member of the tribe and outside the prohilited degrees, is concloned." Here, too, we meet as usual considerable variance of practice. Among some incontinence within the tribe is little regarded. Among others when the results of incontinence

1 Crooke, $\imath b i d$., iv, 24 ; iii, $421,481$.

2 Crooke, ibid., i, 3, 225 ; ii, 7 ; iii, 244 ; iv, 65. Risley, ibid., ii, 69. Crouke, ibid., i, 225 ; ii, 77, 180, 249 ; iii, 421.

${ }^{3}$ Crooke, ibid., iii, 408 ; ii, 324, 283.

4 Risley, ibid., i, 401 (Kândhs); ii, 83 (Mauliks); ii, 102 (Mundiıs); ii, 116 (Musahaus) : ii, 141 (Orầns); ii, 334 (Turis). Crooke, ibid., i, 223 (Basurs); i, 243 (Beriyas); i, 284 (Bhangis); ii, 57 (Bhoksas); iv, $3\{$ : (Thârus). 
become apparent the pair are married under orders of the Council. ${ }^{1}$ In other cases, again, a sacrifice of expiation is required; or this takes the form of a compulsory feast to the tribesman, which the relatives of the girl are bound to provide. ${ }^{2}$ Or in other cases the paramour is fined or has to give restitution. 'This among the Dharkârs is so common that there is a special name, "the mother's sheet," for the cloth which moler such cases the lover has to provide. ${ }^{3}$ It is only among the more degraded scavenger tribes that the taboo against counexion with an outsider is relaxed. These tribes habitually recruit their numbers from abroad and treat as legitimate the children of their women when the father is drawn from a caste superior to their own. ${ }^{4}$

The custom of group-marriage has other developments which it is sometimes not easy to trace. Tlus, it probably accounts for some or most of the marriage taboos which are so common in savage life. The most common of these taboos is that which prevents a man from aldressing, touching, or even looking at his mother-in-law. This has been explained by Sir John Lubbock ${ }^{5}$ as a survival of marriage by capture, the relatives of the bride being hostile to the man who has captured their woman ; or, as by Mr. Keane, ${ }^{6}$ from the analogy of the Patagonian practice that on the death of any young person the head of the family was required to despatch some aged woman, and he naturally selected his mother-in-law as the appropriate victim. Hence, it is said, through fear of such a fate, women acquired the habit of avoiding their sons-in-law.

It would be dangerous to assert that all savages have arrived at the same custom by the same route, but in the Patagonian rite it would rather seem that the specialisation of the mother-in-law was a later phase. At any rate it is hardly logical to treat the mother-in-law taboo apart from other taboos of the same class. Thus, among the Dravidians one of the most important of the marriage taboos is that which prevents a man from coming in conlact in any way with the wife of his younger brother. Most of these races protect her from her senior brother-in-law by a most stringent sanction, which, in the case of the Dharkârs, reaches the point that a man contracts a stain if her shadow even crosses his path. ${ }^{7}$

Sccondly, comes the taboo of the wife's elder sister. A man may marry two sisters, but he may not marry the elder if the younger be already his wife. She is said to be in the position of mother to her younger sister, but this is obviously a later development of the taboo. ${ }^{8}$

1 Risley, ibid., i, 91 (Bhakats); ii, 122 (Bhumij); ii, 57 (Males); ii, 89 (Mech); ii, 243 (Savars); ii, 324 (Tipperahs). Crooke, ibid., ii, 87 (Bhuiyas); ii, 412 (Ghasiyas).

- Risley, ibid., ii, 57 (MalAss). Crooke, ibid., ii, 168 (Châis); ii, 218 (Cheros); iii, 218 (Kewats) ; iii, 419 (Majhwârs); iii, 419 (Mallâhs).

3 Crooke, ibid., ii, 87, 280.

5 Origin of Civilisation, 11 seqq., 192.

4 Crooke, ibid., i, 169.

- Ethnology, 218.

- Risley, ibid., ii, 141 (Orâons). Crooke, ibid., i, 220 (Bhangis); ii, 10 (Bhars); ii, 84 (Bhuiyas) ; ii, 97 (Bhuiyârs); ii, 139 (Biyârs); ii, 190 (Chamârs); ii, 287 (Dharkâr's); ii, 339 (Doms) ; ii, 418 (Ghasiyas); iii, 113 (Kalwâr's) ; iii, 252 (Khar'wârs); iii, 262 (Khatîks) : iii, 314 (Kols) ; iii, 333 (Korwas) ; iii, 444 (Majhwârs).

${ }^{8}$ Risley, ibił., ii, 141 (Orînons). Crooke, ibid., ii, 97 (Bhựyâr's); ii, 139 (Biyâr's); ii, 287 (I)harkârs); iii, 314 (Kols). 
Thirdly, we meet with taboos of more distant female relations-the maternal aunt, the first cousin on the mother's sicle, the relation of Samchi, that is, persons allied by the marriage of their children. ${ }^{1}$ Among the Pankas the father-in-law and mother-in-law of a married pair do not speak to each other. ${ }^{2}$ So we find taboos of the wives of the paternal uncle and nephew." Among the Majhwârs a woman may not address her father-in-law by name. ${ }^{4}$ Lastly and most signiticantly, the Korwas extend the taboo to their sister. ${ }^{5}$

I venture to suggest that the real explanation of this group of marriage taboos is to be found in the fact that they include persons with whom under the primitive rule of group-marriage connexion was permissible. These taboos persisted long after the social system which gave them birth had disappeared, and they had been replaced by a new series of exogamous rules and prohibited degrees.

Survivals of the same system of group-narriage may also be found in the body of custom according to which relatives on both sides aid or resist the bridlegroom as he meets the bride. We have, first, the cases in which the female relatives of the bride resist the bridegroom. Thus, among the Maghs, the female relations of the brice bar the way of the bridegroom with a bamboo, across which he has to drink spirits with them; among the Ahîrs and Majlıwârs the sister-in-law of the brirle prevents the bridegroom from carrying her into the retiring loom; among Baheliyas, when he comes into the room she sits on his back and has to be fed before she will release him; among the Kândhs, after the marriage has been concluded, the bride's male relations rum away with lier, while the village girls recapture her and restore her to her husband; among the Dângis, the bridegroom strikes the marriage shed with a fan and the bricle's female relations beat the man who carries him. ${ }^{6}$ It is not easy to correlate these customs under any one general principle. Partly they may suggest capture marriage, partly compensation to the relatives of the bricle for the loss of her services, or they may be in part a survival of a stage of Beena marriage in which the bridegroom became entitled to all the sisters.

Even more puzzling are the cases in which the relations of the bridegroom obstruct him. Thus, among the Bhuiyas, when the bridegroom is starting, his mother detains him and must receive a gift before she releases him; the Agariya and Biyâr bridegroom's sister bars the entrance of the bride into her husband's house and demands a present. ${ }^{7}$ Among the Gadariyas there is a mimic struggle

1 Risley, ibid., ii, 141 (Orâons). Crooke, ibid., iii, $2 \tilde{2} 2$ (Khar'wârs). Crooke, ii, 10 (Bhars) ; ii, 54 (Bhuiyas); ii, 139 (Bhuiyârs); ii, 287 (Dharkârs) ; ii, 418 (Ghasiyas); iii, 262 (Khatîks); iii, 314 (Kols); iii, 444 (Majhwârs).

${ }^{2}$ Crooke, ibid., iv, 118.

"Crooke, ibid., ii, 97 (Bhuiyas) ; ii, 190 (Chanıâr's) ; iii, 113 (Kalwârs).

- Crooke, ibid., iii, 444.

5 Crooke, ibid., iii, 333.

${ }^{6}$ Risley, ibid., ii, 31. Crooke, ibid., i, 61 ; ii, 422 ; i, 108. Risley, ibid., i, 402. Crooke, ibid., ii, 249.

' Crooke, ibid., ii, 77 ; i, 4 ; ii, 134. 
between the relations of the bride and bridegroom at the home-coming. ${ }^{1}$ Here we may guess a case of the transition from father-right to mother-right, or an indication of the disuse of Beena marriage, and in lieu of it, the rule of bringing the bride to the house of her husband, the same development of custom being seen in the common plan of erecting the retiring room at the house of the bride as well as that of the bridegroom. On the other hand, there are cases, as among the Kharwârs, where the bride at the home-coming refuses to dismount from her litter and enter the house of her husband until her mother-in-law gives her a present, or as among the Koiris, where the bridegroon's sister gives a fee to the bride as she dismounts. ${ }^{2}$ So among the Hos if the bride be taken to her husband's house and married there, not at her own, she runs away after three days, and the bridegroom is obliged to recapture her by force. ${ }^{3}$ These customs possibly point to a disuse of Beena marriage, but this series of facts is so intricate that it is hardly safe to dogmatise about them.

The line, again, between customs such as these, and survivals of actual marriage by capture cannot easily be drawn. Many incidents in the ordinary Hindu marriage rites have been explained as pointing in the same direction-such as the objection to marrying in neighbouring villages, the formal nature of the marriage procession in which only males take part, and all are mounted or armed; the arming of the bridegroom, the rule that they arrive at the bride's village late in the afternoon or by night; the mock fight at the bride's door, the refusal of entertainment at the hands of her friends, the bloody hand stamped on the shoulder of the boy's father as he goes away, the wailing of the bride as she is carried off, the taboo of the bride's village to her husband's relations after the marriage, the abusive terms applied to male relations by marriage, and so on. ${ }^{4}$

Had time permitted, it might be possible to suggest other explanations of some of these customs. Thus, the arming the bridegroom is possibly a prophylactic against evil spirits, and this also may explain cases in which the bride ceremoniously assaults her husband. Thus, among the Kanjars after marriage the pair go to a tank and the bride strikes the bridegroom with a whip of cloth specially made for the purpose ; or among Dhuniyas, when the bridegroom arrives the bride strikes him two or three times on the head with a small stick. ${ }^{5}$ From the analogy of parallel cases, which are many, it might be suggested that the common custom of flagellation, with the object of expelling evil spirits, may be at the root of the matter. ${ }^{6}$

There are, however, cases in which the custom of marriage by capture seems clear. Thus, at an Agariya marriage the bride hides in the house and is dragged out by the bridegroom; the Bhuiyâr girl wrestles with the youth as he applies

\footnotetext{
${ }^{1}$ Crooke, ibid., ii, 362.

' Risley, ibid., i, 325.

s Crooke, ibid., iii, 142 ; ii, 298.

? Crooke, $\imath b i d .$, iii, 246, 290.

${ }^{4}$ Crooke, ibid., iv, 390 seq.

- Crooke, Popular Religion and Folk-lore, i, 99, 155.
} 
vermilion to her hair; the Sânsya bridegroom hauls the bride seven times round the marriage pavilion and then applies vermilion to her hair. ${ }^{1}$ We know that up to quite recent times the Thârus of the lower Himâlaya used to obtain their brides by capture from other tribes. ${ }^{2}$

Passing on to other modes of marriage, we find that Beena marriage, or as it is called Gharjaiyân, which means that the bridegroom lives with the family of his bride, prevails among many of these tribes. ${ }^{3}$ The period of probation during which the Dravidian Jacol serves for Rachel is a year among the Ghasiyas, and among the Gonds from seven or eight months to three years or more. ${ }^{4}$ Here we have a survival of the practice by which the bridegroom was adopted into the kin of the bride.

The opposite conception, by which the bride was introduced into the kin of the bridegroom, appears in many marriage rites, though here, too, there is a trace of the older rite in confarreatio or eating of the pair together, which is generally done at the house of the bride, the modification of custom being shown in the etiquette by which the youth refuses to eat with his wife at her house until he receives a gift. ${ }^{5}$ But the more important confurrectio rite is carried out at the house of the bridegroom. Thus, the Majhwâr bride is not allowed to enter her new hoine till she and her husband eat rice boiled in milk; and to illustrate the sacramental conception of this meal, we find that the Dholi youth does not eat boiled rice until he tastes it for the first time at his wedding feast, and the Sânsya and Majhwâr bride after her home-coming has to cook for the kinsfolk of her husband, while among the Musahars new fire is solemnly made for the cooking sacrament. ${ }^{6}$ We have, I need hardly say, a survival of the same rite in the solemn cutting of the wedding cake by our brides.

This marriage sacrament, too, often takes the form of a solemn drinking rite, as of the parents of the pair who, on betrothal, solemnly drink together out of platters made of the leaves of a holy tree, or bride and bridegroom drink together, or join in drinking with the clansmen. ${ }^{7}$

More obvious still is the motive of the blood covenant. Here we can observe the stages of the degradation of custom from the use of blood clrawn from the little finger of the husband which is mixed with betel and eaten by the bride among some of the Bengal tribes. ${ }^{8}$ The next stage comes among the Kurmis, where the blood is mixed with lac dye. ${ }^{9}$ Lastly, come the rites common to all these tribes by which the bridegroom, often in secrecy, covered by a sheet, rubs vermilion on

1 Crooke, Tribes and Castes, i, 4 ; ii, 87, 91 ; iv, 129, 280.

= Crooke, ibid., iv, 389.

3 Risley, ibid., ii, 202 (Rautiyas). Crooke, ibid., ii, 89 (Bhuiyârs); ii, 218 (Cher’os); ii, 414 (Ghasiyas) ; ii, 434 (Gonds); iii, 242 (Khar'wâr's) ; iii, 42 (Majlıwârs); iv, 128 (Parahiyas).

4 Crooke, ibid., ii, 414, 434.

c Crooke, ibid., iii, 419 ; ii, 292 ; iii, 426 ; iv, 253, 25.

- Crooke, ibid., ii, 76, 290. Dalton, Descriptive Ethnology of Bengul, 193. Crooke, loc. cit., iii, 423, 24 ; ii, 290.

${ }^{8}$ Risley, ibid., ii, 189, 201.

? Risley, ibid., i, j̈32. 
the parting of the girl's hair and the women relations smear their toes with lac dye-all palpable degradations of the original blood rite. That the rite is sacramental is clearly shown by the fact that the widow after her husband's death solemnly washes off the red from her hair or flings the little box in which she keeps the colouring matter into running water. ${ }^{1}$

The wife is thus by the blood sacrament introduced into the sept of her husband. But a further precaution is necessary to symbolise that she throws off all connexion with her own clan. This tribal totem is often generalised by a row of clay images of parrots which are fixed on the marriage shed. ${ }^{2}$ This is knocked down by the bridegroom, and the remains are scrambled for by the ummarried youths of the tribe, who by this influence hope to share in the symbol which will aid them in clue time to enter the marriage state. ${ }^{3}$ Or the tribal mark takes the form of conventional ornaments, known as the Toran, which are hung over the door of the bride, and these the bridegroom demolishes, sometimes using for this purpose the branch of a sacred tree. ${ }^{4}$ The same rite, I venture to suggest, shows itself in the custom by which at the end of the marriage the youth's father shakes the pole of the wedding shed, which can hardly imply capture or resistance, because he is given a present for so doing. ${ }^{5}$ A further development of custom is shown in the rite where five piles of rice are placed on a curry-stone and the youth grips the girl's ankle and makes her knock them down with her toe. The words denoting the pile of rice and the exogamous group are the same, and the rite seems to symbolise the fact that the bride has now solemnly abandoned her own group and entered that of her husband. ${ }^{\circ}$

Another series of marriage rites seems to be largely based on the desire to bring the wedded pair into intimate connexion with the reproductive powers of nature. This, in India at least, seems to be one explanation of the widespread custom of tree-marriage. One, and the most usual means of establishing communion between the worshipper and his deity is an offering, as we find it for instance in the familiar custom of dedicating the first-fruits. Hence seems to have arisen a very similar idea in the case of marriage, as we see in the numerous instances of the marriage of girls to a god as a preliminary to human marriage. In tree-marriage, then, the bride is first brought into communion with the spirit, which occupies and animates the tree and by the communion shares in its fertility.

The custom of tree-marriage is familiar to the Dravidians, the tree usually selected being one regarded as sacred such as the mango, the mahua, the siddh.? In the original form of the rite the tree seems to have personified the bridegroom, as we see in the Gandhabanik ritual, where the youth climbs a tree and the bride

1 Crooke, ibid., ii, 135, 269.

3 Crooke, $2 b i d$. ., iv, 464 ; iii, 245.

${ }^{2}$ Crooke, ibid., ii, 464 ; iii, 308 ; iv, 21.

4 Crooke, ibid., iii, 482, 486.

s Crooke, ibid., iv, 22 ; ii, 111 ; i, 134 ; iv, 63.

Crooke, ibid., ii, 284 (Dharkâr's); iii, 425 (Majhwârs).

: Risley, ibid., i, 293 (Gonds); i, 475 (Khar'wârs); i, 531 seq. (Kurmis); ii, 41 (Mahilis); ii, 102 (Mundas); ii, 201, Rautiyas ; ii, 229 (Santâls). C'rouke, ii, 78 (Bhuiyas); ii, 363 Gadariyas); iii, 374 (Lohn̂r's); iv, 366 (Pâtur's). 
is carried on a stool seven times round him. ${ }^{1} \quad$ This ritual of walking round the tree in the course of the sun is common to these tribes, and then by a natural development of custom the tree becomes the centre pole of the marriage pavilion, which itself symbolises the over-spreading branches. ${ }^{2}$ Later on the pole becomes a spear fixed up in the shed. ${ }^{3}$ In most cases the shed is built of branches or poles of the tree held sacred by the tribe. ${ }^{*}$ Its significance is clear in the case of the Dharkârs, who make the wedding fire-offering under the sacred tree. Nearly all these tribes also arrange a special booth into which at the close of the service the youth leads the bride. Thus, in the Hâbûra ritual, when the wedding is over one of the tribesmen mounts a horse and rides some distance over the plain close to the camp. The bridegroom takes the opportunity of leading the girl into the shed and consummates the marriage. ${ }^{5}$

The same desire to secure communion with the spirit of fertility embodied in the tree appears in the customs of the tree-dance, which is done on a date associated not only with the growth of the crops and with harvest, but with the seasonal period for marriage and the annual saturnalia, and in the rite of burning the Sambat or sacred tree, which is consumed to symbolise the birth of the new year and the revival of vegetative life. ${ }^{6}$

The same principle explains other marriage rites, such as that the wedded pair are seated on mats of holy leaves; that the anointing is done with wisps of the sacred Kusa grass; that the union is effected by the interchange of garlands or a flower is placed by the youth in the girl's hair.' To us it has come down in the orange blossoms and bridal bouquet.

Hence divorce, the abolition of the marriage covenant, is symbolised by the tearing of a leaf of the holy tree or of a piece of grass, or the plant itself is retained as a life token, a pledge of fidelity. ${ }^{8}$ Or the tree itseif is associated with birth, and as among the Mushars, the child is named from the tree under which it happens to be born, or a leaf of the holy tree is given as a remedy in cases of difficult delivery. ${ }^{9}$

It is by a natural development of ritual as the tribe advances from a rude jungle-life to a settled career dependent upon agriculture, that the kindly influences of mother earth and of the cultivated fruits of the soil are brought into communion with the pair at marriage. We see this in the institution of the Matmangara or sacred earth at marriage, which is dug with various mystic rites and often used to

1 Risley, ibid., i, 266.

2 Crooke, ibid., ii, 283 (Dharkârs); ii, 324 (Doms); ii, 344 (Dorhas); ii, 415 seq. (Ghasiyas).

3 Crooke, ibid., iii, 442 (Majhwârs).

${ }^{4}$ Risley, ibid., i, 532 ; ii, 31, 41, 49, 69, 126. Crooke, ibid., i, 4, 107, 170, 281 ; ii, 180.

$s$ Crooke, ibid., ii, 475 seq.

6 Risley, ibid., ii, 70, 145. Crooke, ibid., ii, 83 ; iii, 145 ; ii, 137, 410.

; Risley, ibid., i, 503. Crooke, ibid., ii, 155, 183 ; iii, 422 : ii, 133 : iii, 244. Risley, ibid., $49,61,97 ; 125,231$.

- Risley, ibıd., i, 533 ; ii, 57, 70, 116, 2:31, 278, 89.

- Crooke, ibid., iv, 27 ; iii, 243. 
form the fireplace on which the sacramental marriage meal is cooked. ${ }^{1}$ Hence also comes the use of grain at marriage which is poured over the bride as a fertility charm. And here in India the usages of two races meet. The Ârayn sacred grain was barley, which among all the Indo-Germanic races is closely associated with sacrifice. The use of wheat is much later, and rice, which we curiously enough have adopted in our own marriage rites, probably came from the Dravidians. In some cases among these jungle tribes the pair touch the holy grain; it is poured over the bride by her brother as she revolves? round the shed, or special wheaten cakes are baked which the married pair tread on, or the women throw packets of betel and handsful of barley over the bridegroom as he enters the house, or a saucer of pulse is placed near the holy water jar and the marriage lamp. ${ }^{2}$ Or again, as among the Orîons, the bride and bridegroom stand on a stone, which is not an Âryan custom, under which a sheaf of corn rests upon a plough yoke. ${ }^{3}$

The ploughshare is again frequently fixed in the centre of the wedding shed; the bride's mother waves it over her head as a charm; or the bride and bridegroom tread on the baskets used on the threshing-floor to avoid the danger of touching the threshold, the barrier which defines the domains of the kindly house spirits and the evil demons who prowl beyond it; or the winnowing fan is used to pour grain over the bride as she moves. ${ }^{4}$

From this class of beliefs we reach a possible explanation of the use of oil in marriage, birth and death rites. Oil is the essence of the tree or plant, and symbolises the life, as fat is the essence of the animal sacrifice and always invested with mystic significance. Thus, we have cases of the burning of the resin of the sacred Sâl tree as a means of expelling evil spirits. ${ }^{5}$ One branch of the Nâgesar tribe uses oil in lieu of vermilion, the survival of the blood covenant. ${ }^{6}$ The use of oil at marriage is common. The bridegroom and bride are anointed with a mixture of oil and turmeric, a mystic plant; at a Dom marriage the fathers of the pair sprinkle oil and turmeric on the ground and invoke the Manes to bring the marriage to a happy issue; the women who dig the sacred earth receive a dole of oil for their hair; the Nat widow at marriage has her head anointed; and among the Bhuiyârs most significantly, the bride's father presses oil with his own hand and sends it to the youth for his anointing. ${ }^{7}$

So in the death rites it symbolises the food for the dead and among the Bhuiyârs it is thrown into running water near the place of cremation; mourners after the burning put oil on their toe-rings, or pass their feet through the smoke of burning oil, or touch oil in which a flower is placed, or rub themselves with oil and turmeric-all devices to scare the ghost which may be clinging to them and

1 Crooke, Popular Religion and Folk-lore, i, 27, 292.

2 Crooke, Tribes and Castes, ii, 486 ; iii, 141, 317, 379 ; iv, 23.

3 Risley, ibid., ii, 142. Winternitz, Trans. Folk-lore Congress, 269.

4 Crooke, ibid., ii, 180 ; iv, 21, 63, 146 ; ii, 268.

5 Crooke, ibid., iii, 445.

- Risley, ibid., ii, 122.

'Risley, ibid., ii, 126, 188. Crooke, ibid., i, 5 ; ii, 90, 324, 353 ; iv, 66. 
avoid the death taboo. ${ }^{1}$ In the birth rites an old woman smears her hand with oil and makes a mark on the wall before the cord is cut. ${ }^{2}$

By a conception akin to those which we have been considering it is easy to understand the desire to bring the married pair into communion with the indwelling spirit which in savage belief causes the springs to flow and the rivers to run. Thus we have the Greek cultus of the nymphs and the belief that rivers and springs are Kourotrophoi, or nurturers of youth, to which the first hair of the child, a sacrifice of part of the child himself, is dedicated. Among the Dravidians the same belief shows itself in many forms-in the pouring of water over the hands of the wedded pair; in the Kalasa or sacred wedding jar placed in the pavilion, in the feet washing which implies that the bride washes of all trace of her original sept, and by tasting the water in which the feet of the bridegroom were washed becomes adopted into his clan; in the sacramental wedding bath in which the bride uses the water which served the same purpuse to her lord; in the floating away in running water of the decorations used at the wedding, and many usages of the same kind. ${ }^{3}$ Hence, by a natural sequence, pouring water over a woman's head is a symbol of divorce. ${ }^{4}$

The same belief shows itself in the woman after child-birth solemnly walking round the village well and smearing its platform with vermilion-again the symbol of the blood covenant. ${ }^{5}$

We thus see that while these Dravidian marriage rites embody some very primitive principles of marriage law, they also show evidence of a clear evolution of custom as the tribe emerges from the old jungle life, and they also illustrate the influence of the usages of other peoples as the forest races come into contact with a higher civilisation.

The same course of evolution is shown in the death rites to which I can now only very briefly direct your attention. The line of cleavage is generally taken to lie between burial and cremation, the former prevailing among people some of whom merely wish to put their dead out of sight, others desire to retain their spirits with them; the other adopted by those who believe that the spirit etherealised and released by fire is thus enabled to rejoin the sacred dead in a special heaven of their own. But this generalisation, attractive though it may seem, hardly covers the whole ground. The value of the evidence from the Dravidian people in this chapter of ritual is that we find among them a distinct evolution of custom through all its successive stages. Some expose the dead, others expose certain persons only; some bury; others are in the transition stage between burial and cremation; others, again, practise water burial or combine it with cremation.

1 Crooke, ibid., ii, 93, 284, 325, 417 ; iii, 433.

${ }^{2}$ Crooke, ibid., iii, 198.

${ }^{3}$ Crooke, $v b i d$., ii, 92 ; iii, 483 ; iv, 21. Risley, ibid., ii, 88, 282. Crooke, ibid., i, 128, 235, 251 ; iii, 260 ; i, 62 ; ii, 78 seq. ; 416 ; iii, 246, 260 ; iii, 425 ; iv, 116.

+ Risley, ibid., i, 533 ; ii, 57.

5 Crooke, ibid., i, 107 ; 170 ; ii, 363, 476 ; iv, 145. 
But here it is necessary to distinguish. It is, I believe, the general rule that children, among whom are included unmarried persons and those who have received no further rite of initiation, are buried, not cremated. ${ }^{1}$ Such persons are regarded as lying under a taboo; for until a child is solemnly introduced into the tribe by the rites of hair shaving or ear piercing, both forms of sacramental sacrifice, he is regarded as a Bhût or devil, and not subject to the tribal restrictions connected with food and so on. The same rule applies to those who perish through infectious disease, snake bite or leprosy. ${ }^{2}$

Combined with this taboo and very closely connected with it is the rule under which priests, ascetics, spirit mediums, elders or men of eminence, are, as a rule, interred, not cremated. Such persons, if their bodies be preserved, are likely to transmit to their survivors in whose neighbourhood they lie their mystic powers, piety, and other virtues. Thus, among the Maghs, the bodies of priests and persons of high social position are dried, embalmed, and kept for a year, after which they are solemnly cremated. ${ }^{3}$ The Thârus bury their eminent dead in the house, as the Vaishnava ascetics do. ${ }^{4}$ The Bishnois bury in the family cow-pen. ${ }^{5}$ Among the Kanjars the spirit medium of their tribal god Mâna is always buried. ${ }^{6}$ The Gusâins, a sect of Saivite ascetics, are buried, and the grave is filled with salt. $^{7} \quad$ But these rules are constantly subject to modification. Thus, the method of disposing of the dead among the Gonds has changed in quite modern times; their elders are cremated, and their women, who, as is common among many savages, are conceived as subject to taboo, are buried. The old custom of house burial has recently been superseded by the use of a tribal cemetery. ${ }^{8}$

One of the earliest forms of disposal of the dead shows itself in the case of the Musahars and many of the lower jungle races, who simply fling the corpse away in the forest or do so after only the most hasty and incomplete cremation. ${ }^{9}$ The Mâlês of Bengal expose in the jungle those who perish of snake-bite or other violent death, the belief being that such persons are taboo and their ghosts likely to prove malignant, in which case it is usually deemed expedient for the survivors to abandon the neighbourhood, permanently or for a time. ${ }^{10}$

It is a further development of the same idea which causes some of these tribes to dispose immediately of the corpses of those who die in a state of taboo and to perform their obsequies after a certain time when the taboo is supposed to be removed. Thus, among the Kaseras those who die a violent death are at once thrown into water, and cremated in effigy six months after death. ${ }^{11}$ So with the Audhiyas, who fling into water the bodies of those who die by drowning or other

1 Risley, ibid., i, 94, 231, 499, 535. Crooke, ibid., i, 7.

2 Risley, ibid., i, 510, 499 ; ii, 206. Crooke, ibid., i, 7.

5 Risley, ibid., ii, 34.

4 Risley, ibid., ii, 318, 342. Crooke, ibid., iv, 394.

s Crooke, ibid., ii, 124.

7 Crooke, ibid., ii, 469.

- Crooke, ibid., iv, 28.

" Crooke, ibid., iii, 170.

- Crooke, ibid., iii, 143.

- Crooke, ibid., ii, 435

${ }^{10}$ Risley, ibid., ii, 59 
accident, poison, cholera, small-pox or leprosy, and within a year cremate them in effigy, a rule which also prevails among the Barhais. ${ }^{1}$

But in most cases we find these people in a stage of transition between burial, disposal in running water or cremation. Thus, among the pure jungle-races those who are more advanced cremate; those less exposed to Hindu influence bury. ${ }^{2}$

Others, again, perform a very imperfect cremation and then bury, as the Bhangis do, who before burial scorch the face or hand, or like the Kanjars, who scorch the left thumb and then bury. ${ }^{3}$ There is some evidence that a mixture of rites like these prevailed among the early European barrow-builders, and some form of embalmment combined with cremation seems to have been the rule at Mycenæ; but the best authorities appear to agree that if the early Greeks adopted cremation it was done only in a very imperfect way. ${ }^{4}$

We also find among some of the Dravidian races the custom of disposing of the corpse in running water, which does not seem to be an Âryan rite, and its appearance among the Gusâin ascetics seems to point to their adoption of some indigenous practices. ${ }^{5}$ Others, again, like the Musahars, ${ }^{6}$ combine cremation with disposal by water, and this has been adopted by modern orthodox Hindus, who collect the bones at the pyre and subsequently fling them into some holy stream.

Lastly, we have cases in which all three modes of disposing of the corpse are adopted. Thus, among the Aheriyas the richer people cremate, the poorer bury or fling the corpse into water; Doms cremate, or bury, or scorch the corpse and throw it into water; the Hâbûras cremate, or bury, or fling into water or expose in the jungle. Even among orthodox Hindus the three methods are adopted; babies they bury; from babyhood till marriage or initiation they use water burial; adults they cremate. We may therefore conclude that various converging strains of influence have combined to establish the current forms of death rites.

One very common method of guarding against the evil influences of persons in a state of taboo is to bury the dead face downwards, to fill the grave with thorns, to pile a heavy cairm over the remains. ${ }^{8}$ With all Dravidians the order of burial is to lay the head to the north and the feet towards the south, the land of the dead, a belief which may have been borrowed from them by the Hindus. Even a more primitive rule is found among the Kabîrpanthi Rautiyas of Bengal, who bury the dead standing, of which there are instances in European tradition, as in

1 Crooke, ibid., i, 90, 194.

. Crooke, ibذd., ii, 284 (Dharkârs); iii, 332 (Korwas); iii, 433 (Majbwârs) ; Central Provinces Gazetteer, 49 (Korkus). Crooke, ibid̄., iv, 393 (Thârus). Risley, ibid., i, 62 (Banwârs) ; ibid., i, 81 (Bauris); ibid., i, 136 (Binjhiyas); ibid., i, 299 (Goriyas), ibid., i, 510 (Koras) ; ibid., ii, 244 (Savars). Crooke, ibid., i, 286 (Bhangis).

${ }^{3}$ Crooke, ibid., i, 286 ; iii, 144.

- Schuchhardt, Excavations, 162 seq. ; 296, 325 seq.

s Crooke, ibid., iv, 28 seq. ; ii, 471.

' Crooke, ibid., i, 44 ; ii, 325, 476.

s Risley, ibid., i, 81, 231, 248, 510. Crooke, ibid., i, 44 ; iv, 66.

- Crooke, ibid., iv, 29. 
the well-known case of Rare Ben Jonson. ${ }^{1}$ We find, again, among the Sannyâsi ascetics a survival of the practice common among other savages of burying the dead in a cramped sitting position, which symbolises the posture of the child in the womb of its mother.

I have, thus, at a length which may, I fear, be considered excessive, endeavoured to bring before you some considerations which may attract your interest to a race which possesses no historical annals, and which has secured little attention from Englishmen. But particularly from an administrative point of view, they are a people of no little importance. Not only does the Queen-Empress rule sixteen millions of pure Dravidians, a population as large as that of Spain, but Southern India has been in the main peopled by them, and, as I have attempted to show, they form a large element in the population of the northern part of the Peninsula, in many respects the most valuable and interesting part of the Empire. It is on the development of this race that our tenure of India mainly depends. Englishmen in India will always continue to form a garrison pledged to maintain the peace, and a small body of administrators whose task it is to develop the resources and train the native races to take their place in the government of the country. But the Englishman cannot live and multiply among the rigorous surroundings of a tropical climate. It is a remarkable but melancholy fact that there is not, I believe, a single lineal descendant in the third generation of the original settlers alive at the present day. The progress of agriculture, which must always remain the leading Indian industry, mainly depends on the Dravidian race.

Hence the study of this people is obviously one of great importance. And in closing, I may venture to suggest that this Institute might be well advised to suggest to the Indian Government a more extensive ethnological and anthropometrical survey of them than has been hitherto attempted. We need one general survey extending through the Peninsula from the shores of the Indian Ocean to those of the Bay of Bengal, and linking together in one well organised scheme, the Bhîl of the West with the Gonds of the Central Provinces, and the Kol, Kharwâr, and Santâl of the eastern portion of the plateau. If I have succeeded in showing that the ethnologist and student of primitive sociology has something to learn from an investigation of these races, my aim in writing this paper will have been fully attained.

${ }^{1}$ Risley, ibid., ii, 205. Crooke, ibid., iv, 275; Wheatley-Cunningham, London Past and Present, iii, 473. 